\title{
GEOTECHNICAL EVALUATION OF ANTHILL SOILS FROM PARTS OF EDO STATE, SOUTHWESTERN NIGERIA
}

\author{
Oluwatomilola Andre-Obayanju \\ Department of Geology, University of Benin, \\ Benin City, Edo State, Nigeria
}

\begin{abstract}
With the increasing rate of infrastructural development within developing Africa and the increase in failure of construction materials, there is need to seek solutions to further improve on the quality of materials used. Soils from anthills have been studied to possess some improved geotechnical properties that may improve the quality of materials used for construction, especially road construction. Soils from anthills were collected from different parts of Edo State, southwest Nigeria and was subjected to some geotechnical tests - Atterberg, compaction, CBR and particle size tests - to ascertain the properties of the soils. The uniformity coefficient and coefficient curvature of the soils indicated that they are good subgrade materials for road construction. This can also be confirmed by the percentage fines of above $28 \%$ for all samples, plasticity index of above 10, optimum moisture content of above $12 \%$ and maximum dry density of 1.65 and above. Values from the soaked and unsoaked CBR tests also conforms with that of a good subgrade material when compared with the USCS and AASHTO classification
\end{abstract}

Keyword: Anthill, Geotechnical, Soil, Subgrade

\section{INTRODUCTION}

In a tropical area such as Africa that is in a phase of infrastructural development, red tropical soils have been, and are still a topic of interest and discussion. Due to the unique favourable engineering properties and the relative abundance of the naturally occurring soils, they have been used in large scale construction including roads, housing, earth embarkment fills, and other types of foundation constructions (Gidigasu 1983; Autret 1983; Ekodeck 1984; Sikali and Mir-Emarati 1986; Bagarre 1990; Tardy 1992 Tockol et al. 1994; Ojo and Adeyemi 2003).

Termite or anthill soils are soils that have been obtained from anthills or termite mound, which is always seen as a pile of earth made by termites and ants resembling a small hill structure. It is made mostly of clay materials and other finegrained soils that the plasticity properties have been further enhanced by the secretions from the insects while being used

\author{
Osayamen Julius Imarhiagbe \\ Division of Earth Sciences and Geography \\ RWTH Aachen University, Aachen, Germany
}

in building the mound (Minjinyawa et al., 2007). The clays and fine-grained soils from the termite mound and anthills is capable of maintaining a definite shape after moulding because of this plasticity; it is also less susceptible to crack when compared with natural clay. Anthills materials are special because they absorb water which when it hits the ant mould the convex dirt tends to beadband run off by the side and subsequently dries out quickly (O'Conell,2015). The end result is a hardened huge soil mass which does not deteriorate even under very extreme weather conditions.

According to Nene et al., (2003), termites are considered as soil engineers because of their effects and modification of soil properties because they stabilize and modify the soils while building their dwellings. According to Nene (2003), the following facts are known about termite and termite hills: they use adjacent soil grains in construction of anthills; these particles are coated with sticky rapidly hardening material secretions from their mouth, on prying the materials become hard rock; strength of the anthill increases with time; Shapes and sizes can vary, being a pyramid, mushroom, column etc. which are indicative of the species of termites. The sizes can be as large as $4 \mathrm{~m}$ at the base and $4 \mathrm{~m}$ high; In spite of the height for giant anthills, no cavity in the ground.

Ants have been known to modify the chemical and physical properties of soils and plants (Holldobler and Wilson 1990). It can therefore be seen that ants are important components of the ecosystem as they contribute a great part of the earth's biomass (Pavaraj et al 2015). When considering the below ground soil processes, ants are important through the alteration of the physical and chemical environment and through their effects on plants, microorganisms, and other soil organisms (Folgarait, 1998).

A study of the geotechnical properties of anthills from Igarra and Benin City, Southwest Nigeria was carried out to determine the strength of the anthill using the basic geotechnical tests (particle size analyses, specific gravity tests, Atterberg tests and compaction tests and also to determine if the soils can be used for stabilization purposes in construction and also for road material improvement. 


\section{International Journal of Engineering Applied Sciences and Technology, 2019 \\ Vol. 4, Issue 7, ISSN No. 2455-2143, Pages 310-315 \\ Published Online November 2019 in IJEAST (http://www.ijeast.com)}

\section{THE STUDY AREA}

The study areas fall in the savannah region with tropical climate which covers most of the western, central Nigeria to some parts of the southern Nigeria. The climate exhibits two major seasons, the well-marked rainy season from April to October and the dry and hot season with harrmattan wind from November to March. The vegetations are characterized by thick, tall bushes which are dense along water channels, shorter trees are scattered all over the area and also there are presence of palm trees. The area is always greenish throughout the wet season and withers in the dry season. The geomorphology of the Igarra area and environs has highlands which stand out as ridges due to their nature of resistance to weathering and lowlands which are less resistant to weathering. The area is underlain by the rocks of the Precambrian basement complex of Nigeria. According to Ajibade (1976), the rocks can be grouped into a simplified three (3) fold subdivision: the migmatite gneiss complex, the monocyclic younger metasediments and the older granites The Benin area is characterized by generally lowlands which have low resistance to weathering. Benin is generally marked by top Red Tropical Soils composed of low silica-sesquioxide ratio clay sand which is soft when wet and considerably hard when dry Alayaki et al, (2015). The lithostratigraphy of the Benin Formation (Miocene- Recent) is characterized by $90 \%$ sand, conglomeratic gravels (pebbles and cobbles), clays, peat and lignite (infrequent; occurring as beds or dispersed fragments) deposited in a continental coastal plain (fluvial) depositional setting (Nwajide, 2013).

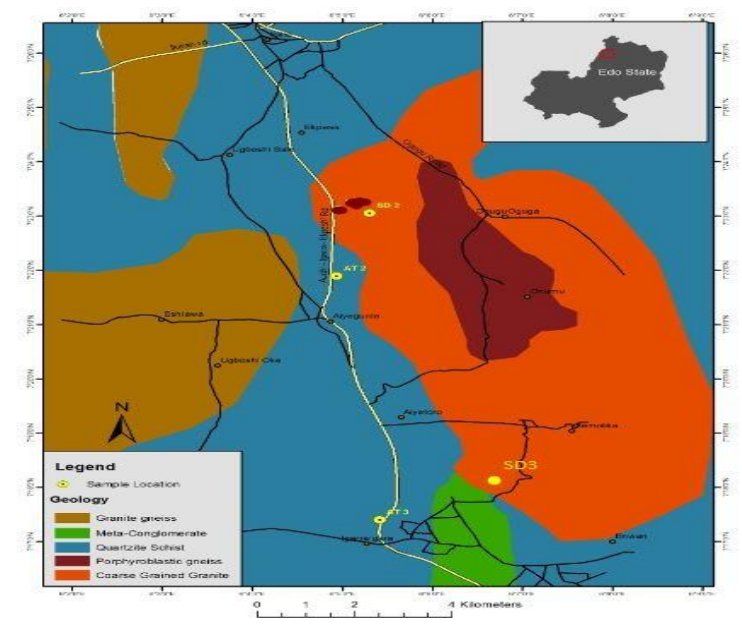

Fig. 1. Map showing sampled areas in Igarra and Environs (After Andre-Obayanju et al, 2017)

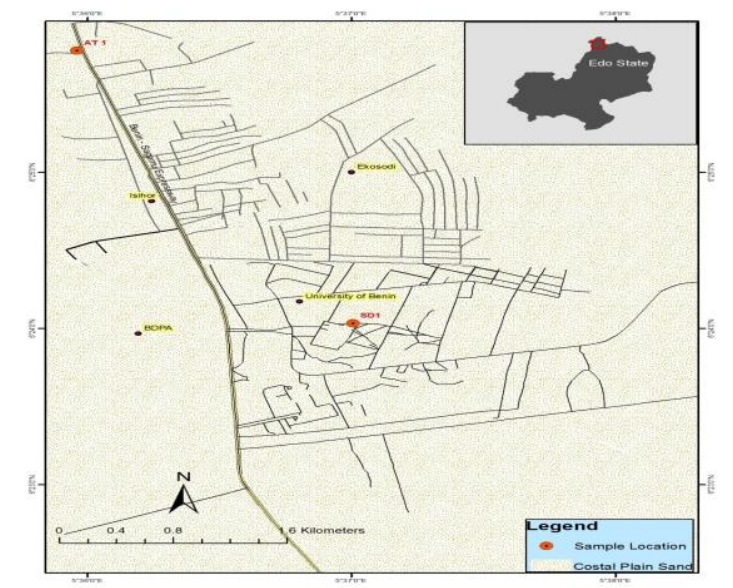

Fig.2. Map of sampled area in Benin

\section{METHODOLOGY}

Reconnaissance survey was carried out in the areas of interest to check availability of anthills within the vicinity. Three samples were collected for the anthills, two samples from the Igarra area and one sample from Benin City. Tests carried out on the soils include sieve analysis (particle size distribution), Atterberg tests, bulk and dry density tests, soil compaction tests, specific gravity tests and California Bearing ratio tests to ascertain the geotechnical properties of the soils. Particle-size analysis was done with a combination of wet sieving and hydrometer method

The moisture content test was used to determine the water content of the soil. Specific gravity is the ratio of the weight of a substance to that of an equal volume of water. The Atterberg Limit test, also known as the Consistency Limit Test is used to determine the effect of moisture content on fine grained soil. It defines the boundaries of several state of consistency of plastic soil. Compaction tests are carried out with the aim of determining the moisture density relationships and change in soils, increase unit weight, shear strength, reducing permeability. This makes the soil less susceptible to settlement under load, especially repeated loading. These soil tests were carried out in the geotechnical laboratory of the Civil Engineering Department, University of Benin, Nigeria in accordance with B.S. 1377. (1975). Compaction was done with the West African standard. 
International Journal of Engineering Applied Sciences and Technology, 2019

Vol. 4, Issue 7, ISSN No. 2455-2143, Pages 310-315

Published Online November 2019 in IJEAST (http://www.ijeast.com)

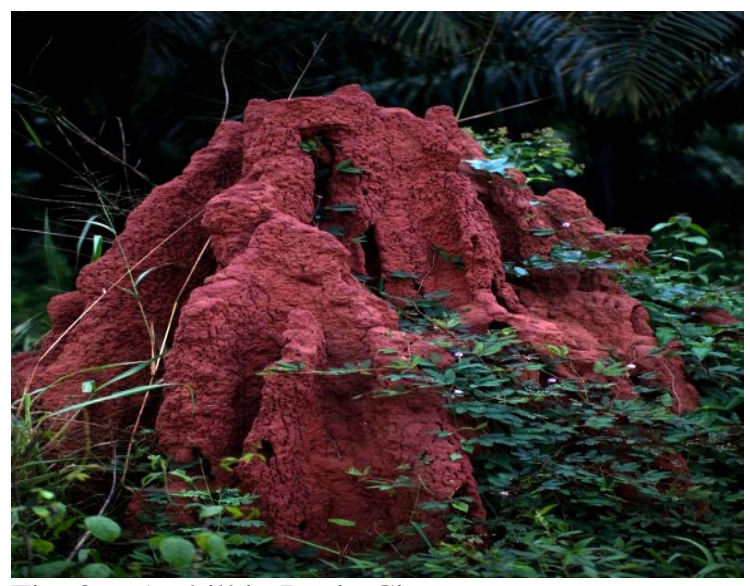

Fig. 3. Anthill in Benin City

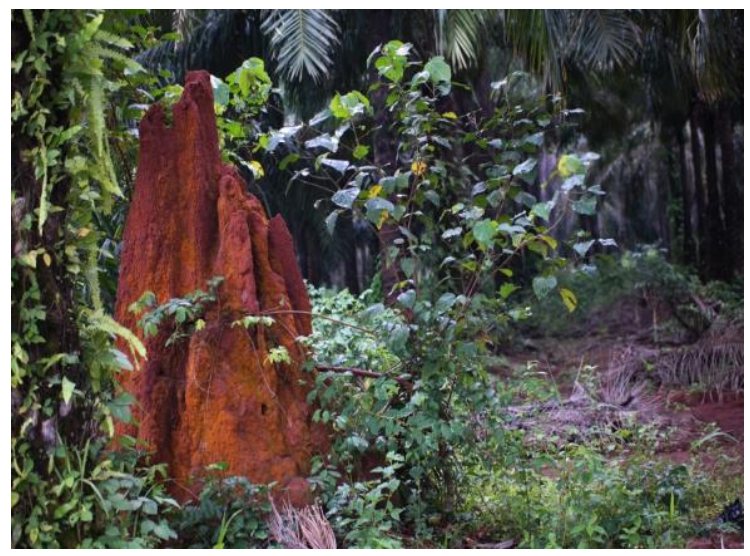

Fig. 4. Anthill in Igarra

IV. RESULTS AND DISCUSSION

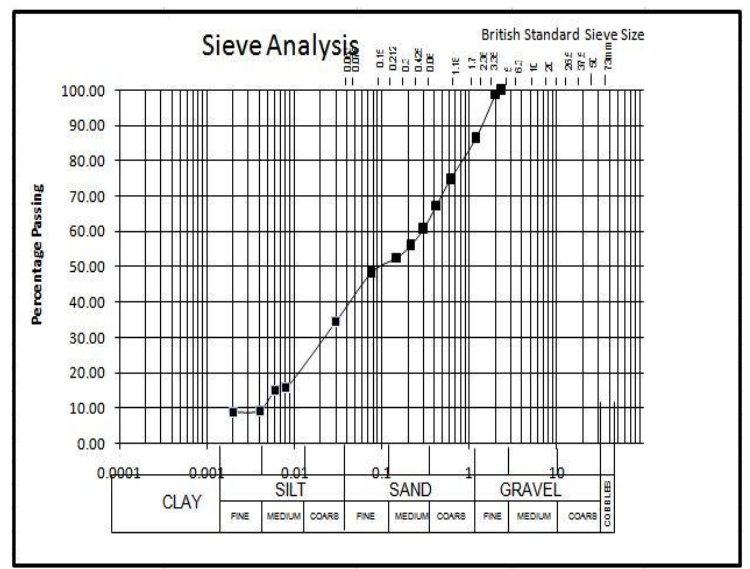

Fig. 5. Particle Size Curve for Anthill 1(A1)

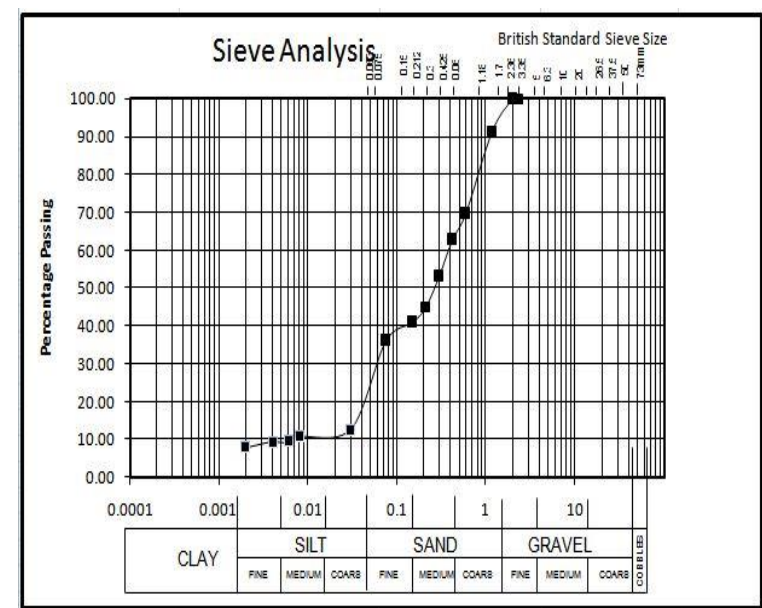

Fig. 6. Particle Size Curve for Anthill 2(A2)

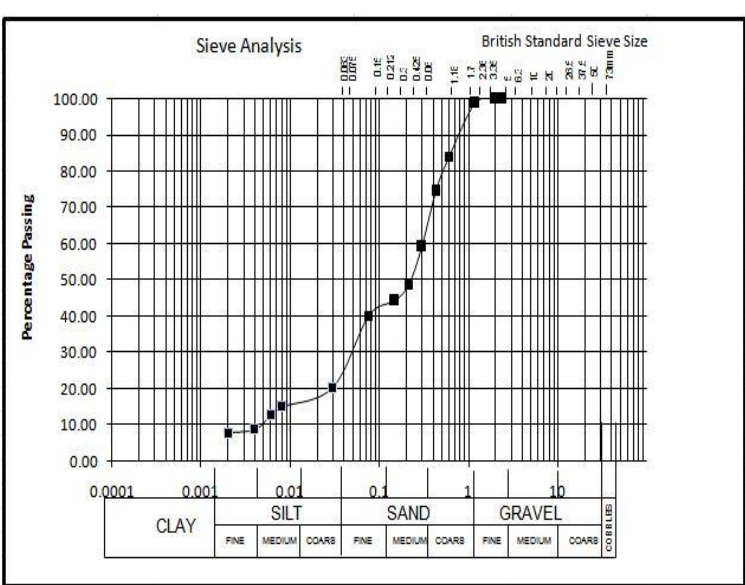

Fig. 7. Particle Size Curve For Anthill 3(A3)

Table 1: Particle Size Analysis

\begin{tabular}{|l|l|l|l|l|l|}
\hline & $\begin{array}{l}\text { Sand } \\
\text { s }(\%)\end{array}$ & $\begin{array}{l}\text { Silt } \\
(\%)\end{array}$ & $\begin{array}{l}\text { Clay } \\
(\boldsymbol{\%})\end{array}$ & $\begin{array}{l}\text { \%Fines } \\
\mathbf{( S i l t +}+ \\
\text { Clay) }\end{array}$ & Soil Type \\
\hline A1 & 66.55 & 18.4 & 10.05 & 28.45 & $\begin{array}{l}\text { Silty-Clay } \\
\text { Sand }\end{array}$ \\
\hline A2 & 65.75 & 25.20 & 8.05 & $33-25$ & Silty Sand \\
\hline A3 & 62.94 & 20.01 & 8.05 & 28.06 & Silty Sand \\
\hline
\end{tabular}

Table 2: Uniformity Coefficient

\begin{tabular}{|l|l|l|l|}
\hline Location & Benin & \multicolumn{2}{|l|}{ Igarra } \\
\hline Sample NO & A1 & A2 & A3 \\
\hline $\begin{array}{l}\text { Uniformity Coefficient } \\
(\mathrm{Cu})\end{array}$ & 200 & 140 & 75 \\
\hline $\begin{array}{l}\text { Coefficient of } \\
\text { Curvature (Cc) }\end{array}$ & 2.9 & 3 & 3 \\
\hline
\end{tabular}

For a well graded soil $\mathrm{Cu}>5,1 \leq \mathrm{Cc} \leq 3$, If these criteria are not met then its poorly graded (it could either be gap graded or uniformly graded. For the samples, the $\mathrm{Cu}$ values are greater 
than 5, while the $\mathrm{Cc}$ values are 3 and below. Also, all the percentage fines are below $35 \%$ for the samples. According to the British standard BC1377 (1990), if percentage fines is less than $35 \%$, its adjudged as a good subgrade material. According to AASHTO the soil samples are A-2-6

Table 3: Specific Gravity

\begin{tabular}{|l|l|}
\hline Samples & Specific Gravity \\
\hline A1 & 2.60 \\
& 2.60 \\
\hline A2 & 2.60 \\
& 2.50 \\
\hline A3 & 2.60 \\
& 2.50 \\
\hline
\end{tabular}

The soils had Gs ranging between 2.50 and 2.60, indicative of the fine-grained soils. This can be classified as good subgrade material for construction purposes (Gidigasu, 1976; Mesida 1981).

Table 4: Plasticity Index

\begin{tabular}{|l|l|l|l|}
\hline & $\begin{array}{l}\text { Liquid } \\
\text { Limit } \\
\text { (LL) }\end{array}$ & $\begin{array}{l}\text { Plastic } \\
\text { Limit } \\
\text { (PL) }\end{array}$ & $\begin{array}{l}\text { Plasticity } \\
\text { Index (PI) } \\
\text { PI= LL-PL }\end{array}$ \\
\hline A1 & 31 & 19 & 12 \\
\hline A2 & 33 & 23 & 10 \\
\hline A3 & 26.5 & 15 & 11.5 \\
\hline
\end{tabular}

\section{CASSAGRANDE PLASTICITY CHART}

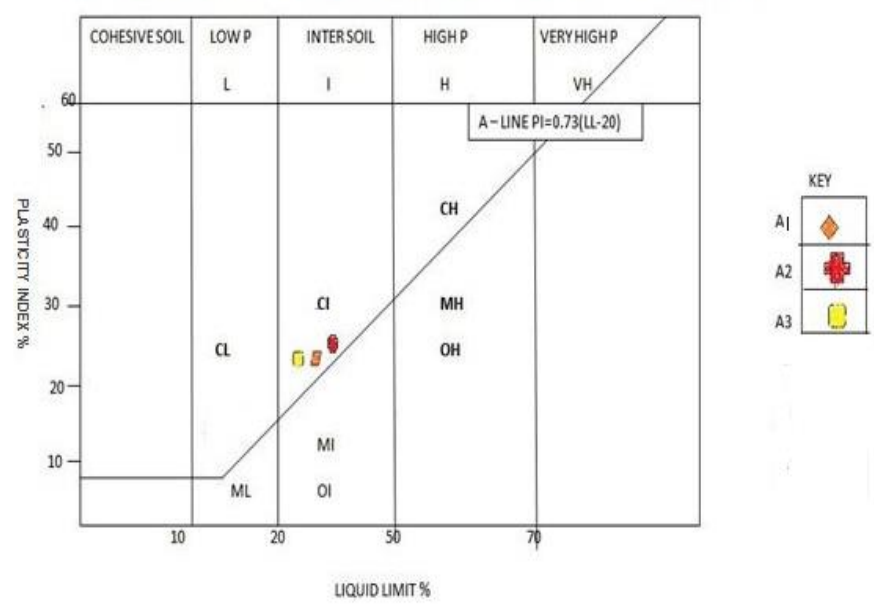

Fig. 8. Cassagrande Plasticity Chart

According to the USCS the anthills soils are CI-Group soils (Fig. 8) and they fall above the A-line indicating an inorganic clayey material for the soils (Casangrande 1948). These are indicative of intermediate soils with low to medium swelling potentials, with no-swelling properties clays. These are well graded soils suitable in road construction.

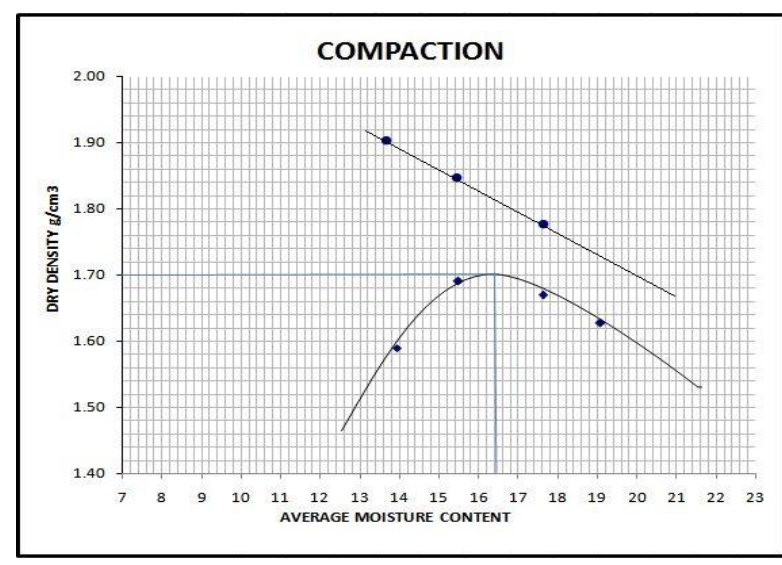

Fig. 9. Compaction Curve for Anthill1 (A1)

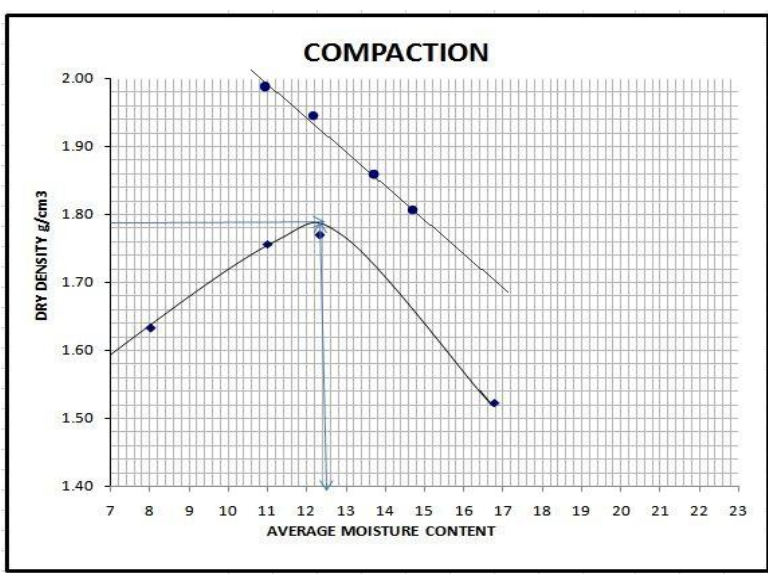

Fig. 10. Compaction Curve for Anthill2 (A2)

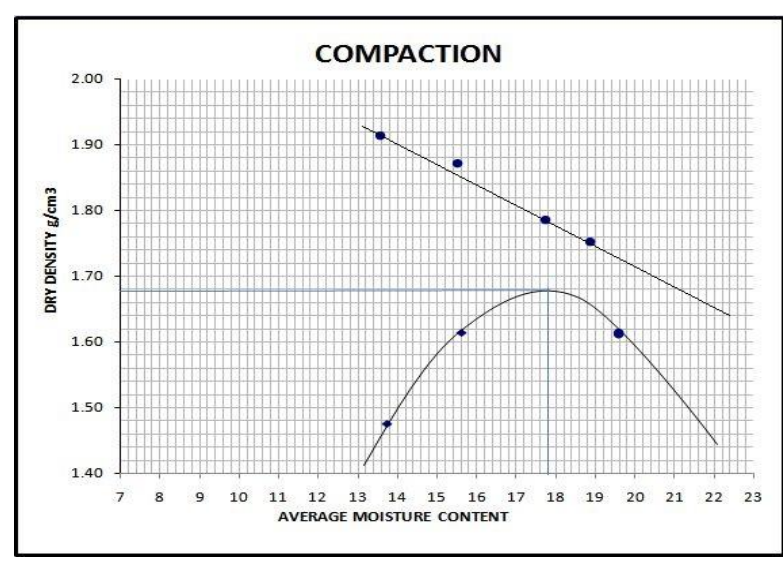

Fig. 11. Compaction Curve Anthill3 (A3)

Table 5. Compaction Results

\begin{tabular}{|c|c|c|}
\hline & $\begin{array}{lr}\text { Maximum } & \text { Dry } \\
\text { Density(MDD) } & \mathrm{kg} / \mathrm{dm}^{3}\end{array}$ & $\begin{array}{l}\text { Optimum Moisture } \\
\text { Content (OMC) \% }\end{array}$ \\
\hline A1 & 1.65 & 17.8 \\
\hline $\mathbf{A 2}$ & 1.71 & 17.5 \\
\hline A3 & 1.8 & 12.5 \\
\hline
\end{tabular}




\section{International Journal of Engineering Applied Sciences and Technology, 2019 \\ Vol. 4, Issue 7, ISSN No. 2455-2143, Pages 310-315 \\ Published Online November 2019 in IJEAST (http://www.ijeast.com)}

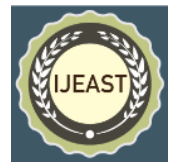

The optimum moisture contents (OMC) of the test samples ranged between $12.5 \%$ and $17.6 \%$, while the maximum dry density (MDD) was between $1.65 \mathrm{~kg} / \mathrm{dm}^{3}$ and $1.7 \mathrm{~kg} / \mathrm{dm}^{3}$ respectively. The samples all had low OMCs and high MDDs and this meets the criteria for the Federal Ministry of Works. The importance of compaction test is to improve the desirable load Bearing Capacity of the soil.

Table 6: CBR Results

\begin{tabular}{|l|l|l|l|l|l|}
\hline \multicolumn{2}{|c|}{} & A1 & A2 & A3 \\
\hline \multirow{3}{*}{$\left.\begin{array}{l}\text { CBR } \\
\%\end{array}\right)$} & Soaked & Bottom & 24 & 21 & 36 \\
\cline { 2 - 6 } & & Top & 22 & 12 & 24 \\
\cline { 2 - 6 } & \multirow{2}{*}{$\begin{array}{c}\text { Un- } \\
\text { soaked }\end{array}$} & Bottom & 25 & 20 & 37 \\
\cline { 2 - 6 } & Top & 25 & 24 & 40 \\
\hline USCS & CI/SW & CI/SW & CI/SW \\
\hline \multicolumn{2}{|l|}{ AASHTO Classification } & A-2-6 & A-2-6 & A-2-6 \\
\hline
\end{tabular}

The California Bearing ratio (CBR) tests for the anthill samples revealed values between $12-24 \%$ and $24-40 \%$ for the soaked and unsoaked tests respectively. This is indicative of the mechanical strength of the soil materials as good subgrade materials

\section{CONCLUSION}

The anthill soils of the areas studied show good geotechnical properties that are favourable for road construction as subsoil materials. The collective properties seem to correspond with the desired properties for construction. However, because these anthills soils may not be gotten on an economic scale, they can act as good stabilizing agents, especially for soils that may have low or unfavourable geotechnical parameters

Termite clay that was obtained from termite mound performed better than ordinary clay when used in construction because the plasticity of the clay had improved from the termite secretion (Minjinyawa et al 2007; Yohanna et al 2003). Millogo et al., (2008) discovered that the termite mound is composed of $46 \%$ sand, $44 \%$ silt and $10 \%$ clay and of medium plasticity.

\section{ACKNOWLEDGEMENT}

The authors wish to thank the Department of Geology, University of Benin, for the opportunity to carryout this research, the Geotechnical Laboratory of the Civil Engineering department, University of Benin for assisting with the soil tests.

\section{REFERENCES}

Ajibade A.C (1976). Provisional classification and correlation of the schist belts of the Northwestern Nigeria, Geology of Nigeria, Elizabeth Publishing Co (pp1143)
Alayaki, F., Al-Tabbaa, A., and Ayotamuno, J., (2015). Defining Niger Delta Soils: Are They Laterites? Civil and Environmental Research www.iiste.org, Vol.7, No.5.

Andre-Obayanju, O., Imarhiagbe, OJ. and Onyeobi, TUS (2017) Comparative Evaluation of Geotechnical Properties of Red Tropical Soils and Anthills from parts of Edo State for Road Construction. J. Appl. Sci. Environ. Manage. Vol. 21 (7) 1250-1255

Autret P. (1983). Laterites et Graveleux Lateritiques:laboratory Central des point et Chausses 1983.

Bagarre, E. (1990). Utilisation des graveleux latéritiques en technique routière (p. 143). Paris: Institut des Sciences et des Techniques de l'Equipement et de 1' Environnement.

British Standard Institution, (1990). Method of test for soils for Civil Engineering Properties (BS1377), British Standard institution, London (pp1143)

B.S. 1377 (1975). Methods of test for soils for Civil Engineering Purpose. British Standard Institution HMSO London.

Casagrande, A. (1948). Classification and identification of soils. Transactions, ASCE, 113, (pp901-930).

Ekodeck, G. E. (1984). L'altération des roches métamorphiques du Sud Cameroun et ses aspects géotechniques. Thèse de Doctorat D'Etat des Sciences Naturelles, IRGM (pp368). France: Université Scientifique et Médicinal de Grenoble I.

Folgarait P.J., (1998). Ant Biodiversity and its relationship to ecosystem functioning: a review, Biodiversity and Conservation 7(9) : (pp1221 - 1224).

Gidigazu M.D. (1976). Laterite soil Engineering.Pedogenesis and Engineering principles. Development in Geotechnical Engineering9, Elsevier Amsterdam (pp554).

Gidigasu, M. D. (1983). Development of acceptance specifications for tropical gravel paving materials. Eng Geo, 19, (pp213-240).

Indraratna, B., and Nutalaya, P. (1991). Engineering characteristics of a compacted, lateritic residual soil. Geotech Geol Eng, 9, (pp125-137)

Holldobler, B. and Wilson, E.O. (1990). The Ants, Harvard University Press, Cambridge, (pp732)

Mesida E.A. (1981). Laterites on the Highway Understanding Soil Behaviour. West African Technical Review, November,1981. (pp112-118).

Millogo, Y., Traore, K., Ouedraogo, R., Kabore, K., Blanchart, P., and Thomassin, J. H. (2008). Geotechnical, mechanical, chemical and mineralogical characterization of a lateritic gravels of Sapouy (Burkina Faso) used in road construction. Const Build Mat, 22, (pp70-76).

Minjinyawa, Y., Lucas, E. B. and Adegunjoye, F. O. (2007), "Termite Mound Clay as Material for Grain Silos Construction", Agricultural Engineering International. The CIGR E-Journal Manuscript BC 07 002. Vol. IX.

Nene A.S and Parihar Y.D (2003). Natural stabilization of expansive soil, Proceeding of Indian Geotechnical 
Conferences 1992. Calcutta 18-20 December 2003 vol1 (pp207-209)

Nwajide C.S. (2013). Nigeria Sedimentary Basins, CSS bookshops limited, Lagos. (pg 321-332).

O'conell R. (2015). The ant colony, Mental floss, Dennis Publishing House, Clevland UK 2015

Odeyemi I.B. (1988). Lithostratigraphy and Structural relationship of Upper Precambrian metasediments in Igarra, Western Nigeria h.p.o Oluyide W.C in Precambrian Geology of Nigeria Kaduna. (pp111-23)

Ojo, J. S. and Adeyemi, G. O. (2003). Opportunities for ventures in construction materials. In A. A. Elueze (Ed.), Prospects for Investment in Mineral Resources of Southwestern Nigeria (pp. 47-54).

Pavaraj, M; Mahadevi, K; Buvaneshwari, R and Rajan, MK 2015. Analysis of Physico-chemical characteristics of ant hill soil and impact of plant growth in the green gram Vigna radiate. International Journal of Current Research and Academic Review. Volume 3 Number 5. (pp341).

Sikali, F., and Mir-Emarati, D. (1986). Utilisation des latérites en technique routière au Cameroun. In Séminaire Régional sur les Latérites: Sols, Matériaux, Minerais, Douala (CMR) (pp. 277-288).

Tardy, Y Tockol, I., Massiéra, M., Chiasson, P. A., and Maiga, M. S. (1992). Pétrologie des latérites et sols tropicaux. Masson (ed) (p. 459).

Tockol, I., Massiéra, M., Chiasson, P. A., and Maiga, M. S. (1994). Les graveleux latéritiques dans les pays du sahel: Cas desroutes non revêtues (pp. 3423-3431). Rotterdam, Holland: 7 ème Congrès International de l'AIG 1994). Les graveleux latéritiques Yohanna et al 2003). 